\title{
The Role of Stone in Island Societies in Neolithic Atlantic Europe: Creating Places and Cultural Landscapes
}

\author{
Gabriel Cooney ${ }^{1}$
}

(Received 22 April 2016; accepted in revised form 9 June 2017)

\begin{abstract}
The focus of the paper is an engagement with the significance of the exploitation of stone sources to make objects, particularly stone axe heads on islands in northwest Europe during the Neolithic period (4000-2500 BC). Case studies of Lambay Island in the Irish Sea, Rathlin Island off the northeast coast of Ireland, and the Shetland Islands explore the use of these three stone sources through the archaeological record, examining the biographies of objects (from quarries, through use, to discard or deposition) and applying a range of approaches to understanding material culture. What emerges is an understanding of the central role these three lithic sources played in how people engaged with and created their island places and landscapes. Through their daily engagement with different stone sources (including the ones focused on here) at a range of scales, people created and sustained social relationships and conventions. Hence it is argued that stone artefacts from local sources played a special role in shaping identities on the three islands.
\end{abstract}

Key words: Neolithic; northwestern Europe; things; islands; axe heads; stone sources; quarries; hoards

RÉSUMÉ. Cet article porte principalement sur l'importance de l'exploitation de sources de pierre pour fabriquer des objets, plus particulièrement les têtes de hache en pierre dans les îles du nord-ouest de l'Europe pendant la période néolithique (4000-2500 A.D.) Des études de cas au sujet de l'île de Lambay dans la mer d'Irlande, de l'île de Rathlin au large de la côte nord-est de l'Irlande et des îles Shetland explorent l'utilisation de ces trois sources de pierre au moyen de données archéologiques, en plus d'examiner les biographies d'objets (depuis les carrières jusqu'à leur rejet ou dépôt, en passant par leur utilisation) et d'appliquer un éventail d'approches dans le but de comprendre la culture matérielle. Tout cela permet de comprendre le rôle central que ces trois sources lithiques ont joué dans la façon dont les peuples ont créé leurs lieux et paysages sur ces îles et sont entrés en interaction avec ceux-ci. À partir de leur interaction quotidienne avec diverses sources de pierre (y compris celles dont il est question ici) à diverses échelles, les peuples ont créé et soutenu des relations et des conventions sociales. Par conséquent, nous soutenons que les artefacts en pierre de sources locales ont joué un rôle particulier dans le façonnement des identités de ces trois îles.

Mots clés : Néolithique; nord-ouest de l'Europe; choses; îles; têtes de hache; sources de pierre; carrières; caches

Traduit pour la revue Arctic par Nicole Giguère.

\section{INTRODUCTION}

Two themes of my current and ongoing research are the use of lithic sources by island societies in Atlantic Europe during the establishment and development of farming societies in the Neolithic period and current theoretical approaches to understanding material culture. In northwestern Europe, there is a recurring pattern of the exploitation of stone sources on islands to make objects, particularly stone axe heads (see discussion in Cooney, 2015). I have been engaged with understanding the significance of this phenomenon through work on three different islands (Fig. 1): Lambay in the Irish Sea (e.g., Cooney, 2005, 2009), Rathlin off the northeast coast of Ireland (Cooney et al., 2012a), and the Shetland Islands that stand between the Atlantic and the North Sea (Cooney et al., 2012b, 2013). Recently I have also had the opportunity to examine current theoretical approaches to material culture (Cooney, 2016). This work provides the basis for a comparative approach to explore the role of these lithic sources and the objects made from them in the creation of cultural landscapes on islands, posing the question of whether different theoretical and methodological perspectives can enrich our understanding of the relationship between people and place.

One of the approaches discussed below is the concept of object biographies or lives (e.g., Appadurai, 1986; Hoskins, 1998; Gosden and Marshall, 1999). In writing about the use of lithic sources and the objects made from them, researchers usually begin by considering the source or quarry sites (Cooney, 2011). Indeed quarries have been identified on the three islands and are important foci of research. However, another striking aspect of the activities of Neolithic people on Lambay, Rathlin, and the Shetland Islands was the deliberate deposition of objects

\footnotetext{
${ }^{1}$ UCD School of Archaeology, University College Dublin, Dublin 4, Ireland; Gabriel.Cooney@ucd.ie

(C) The Arctic Institute of North America
} 


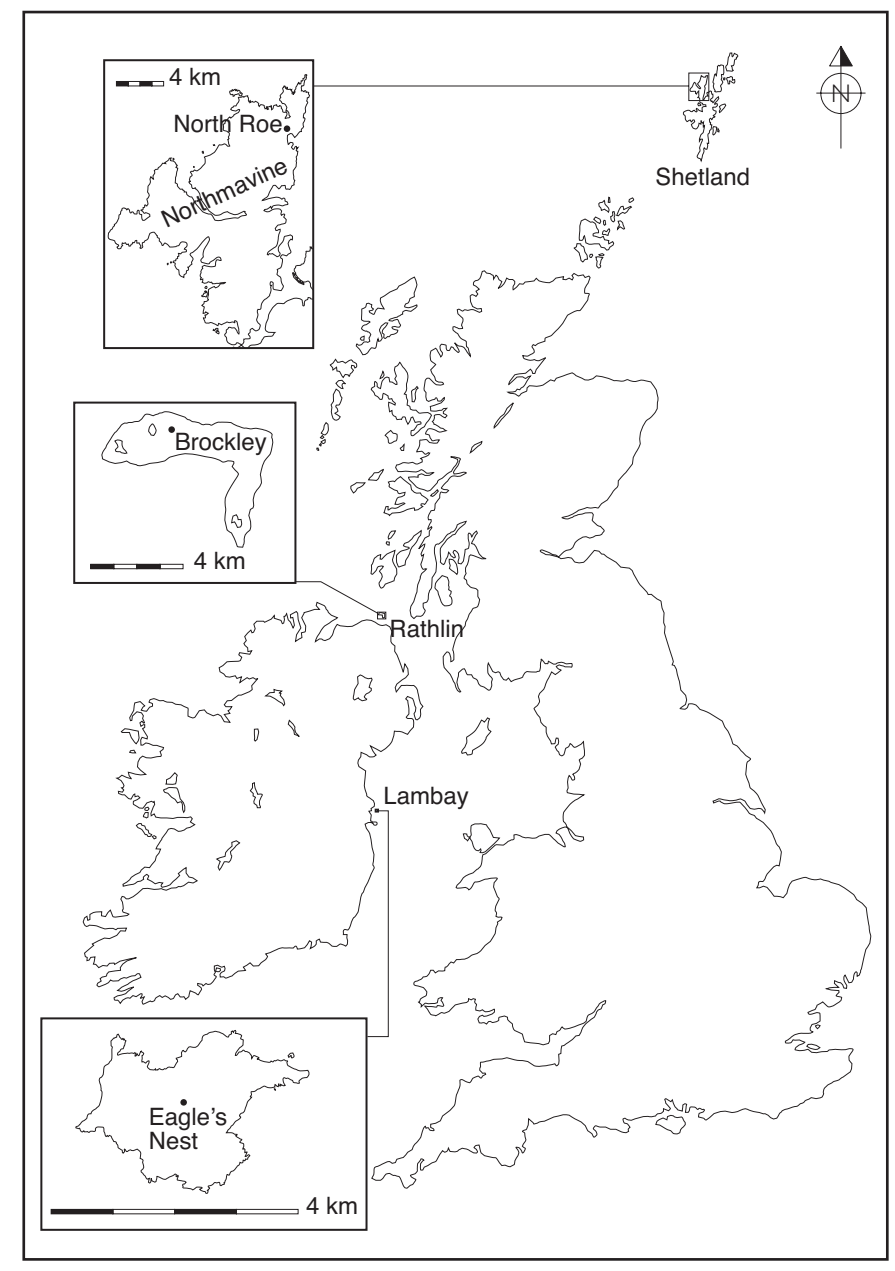

FIG. 1. Location of Rathlin, Shetland, and Lambay Islands in relation to Ireland and Britain.

whose origin lay in these quarries back in the ground, in the form of hoards or caches. This phenomenon is a useful, reflective place to start examining the role of such objects, considering examples in which the last act in the use of objects was their placement back into the physical environment. Taking a broader perspective on early farming societies in Europe, the deposition of hoards is also a widely recurring feature of the European Neolithic (e.g., Cordier and Bocquet, 1998; Pétrequin et al., 2012), which suggests that it was a recurring theme in the engagement of people with the material world.

Hence this paper employs different modes of 'tacking' to work with the archaeological record of three Neolithic island societies: first moving across and along the historical trajectory of objects from deposition back to quarry; second, using different theoretical approaches to understand the place and roles of such things and activities as part of the engagement between people and materials; and finally, asking how these specific island engagements might provide a wider understanding of island societies in Neolithic northwestern Europe.

\section{BURYING THE HATCHET: BEGINNING AT THE END}

Brockley on Rathlin Island is one of two known exploited sources of porcellanite, a fine-grained metamorphic rock that takes a conchoidal fracture and accounts for at least $50 \%$ of the 21000 or so stone axe heads known from Ireland (Cooney and Mandal, 1998, 2000). The large quantity of porcellanite objects known from Rathlin (Cooney et al., 2012a) includes a group of five stone axe heads formerly in the Morris collection and now in the National Museum of Ireland. This hoard (Fig. 2) comprises one complete and a portion of another polished porcellanite axe head, two porcellanite roughouts or preforms, and a ground shale axe head.

A striking feature of the production of axes and objects known as Shetland knives from riebeckite felsite, an igneous rock occurring in the form of intrusive dykes in granite country rock at the quarry complex at North Roe, on the Northmavine peninsula of Mainland Shetland (Ballin, 2011a, b; Davis, 2012), is the occurrence of hoards of both axes and knives. The most spectacular of the latter is the Stourbrough knife hoard (Fig. 3), composed of 19 knives, each placed upright and bookended by sandstone blocks. The hoard was found in eroding peat near the summit of a hill in West Mainland (Fojut, 2006). The primary method of working felsite is by flaking, although some varieties of the rock do not take a clean conchoidal fracture.

On the island of Lambay, a distinctive medium-grained igneous rock, porphyritic andesite (popularly known as porphyry), was used to make stone axe heads. The primary process of working this stone was by hammering and pecking (see Cooney, 2005, 2009). A striking feature noted in the quarry site excavation at the Eagle's Nest was that alongside the quarrying of outcrops for axe head production, there was a recurring practice of deposition of a range of materials. Specific episodes of deposition can be recognized. One of these, which occurred in the Middle/ Late Neolithic around $3000 \mathrm{BC}$, involved the placement of a porphyritic andesite polished axe head, a porphyritic andesite roughout or preform, a sandstone axe head, an unfinished gabbro mace head, and a cobble of jasper that may have been chosen because in size and shape it broadly resembles the axe head form of other objects (Fig. 4).

The hoards discussed above share a number of features. They are the result of deliberate human intent, and while we don't know the detail of the placement of the Rathlin hoard, the locations of the Stourbrough and Eagle's Nest hoards appear to have been deliberately selected. In each case, the composition of the hoard focuses on a major island lithic source that was exploited, but other materials are deliberately included. In the Rathlin and Eagle's Nest hoards, there seems to be a deliberate inclusion of both roughouts or preforms and finished axe heads. Furthermore, it is tempting to suggest that the sandstone blocks in the Stourbrough hoard may refer to the act of grinding and polishing the knives. But can we move out from these 

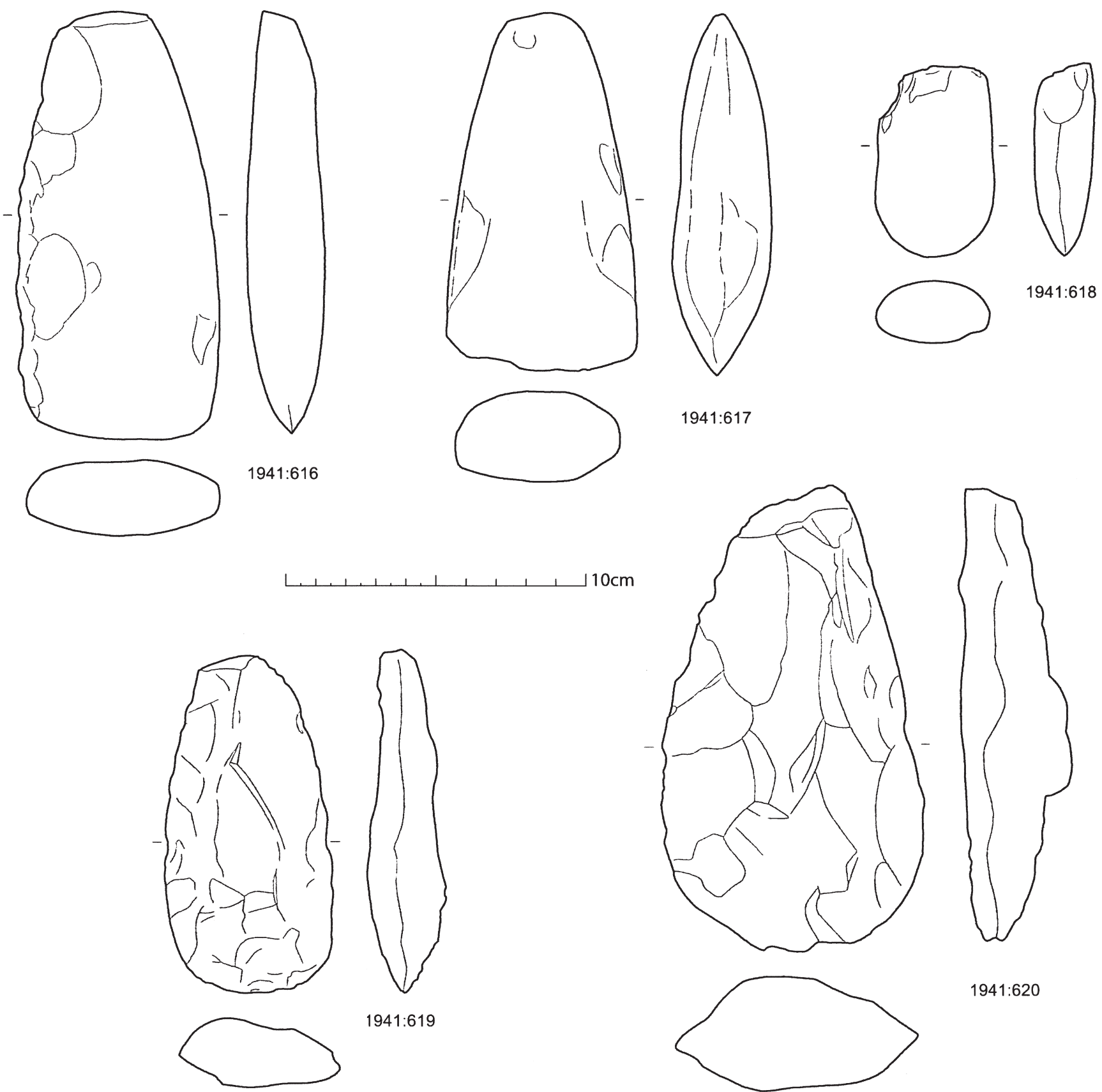

$10 \mathrm{~cm}$
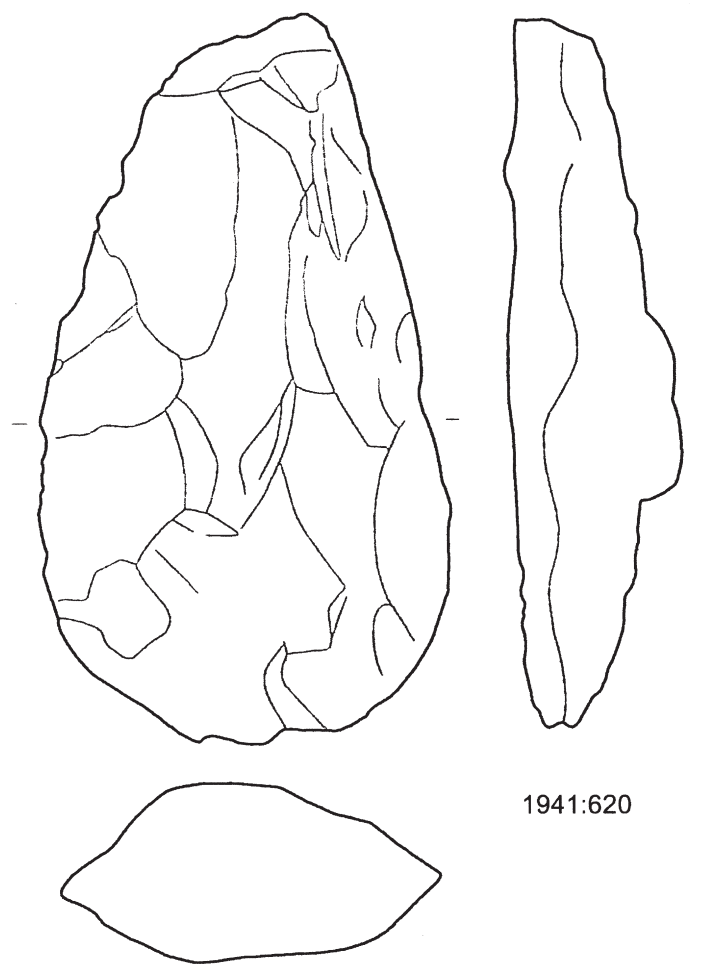

$1941: 620$

FIG. 2. Axe hoard from Rathlin Island: NMI 1941:616 (shale); NMI 1941:617-620 (porcellanite).

interesting, specific actions, with their intimations of complex relationships, behaviour, and engagement with the material world, to a wider understanding of the role of the lithic sources on these three islands and the objects made from them during the Neolithic?

As a starting point, it is useful to refer to Hodder's comment (2011a) that we have reached an interesting juncture in archaeology and related disciplines: there is now general agreement that humans and human social life depend on things. Given the prominence of porcellanite (Rathlin), riebeckite felsite (Shetland), and porphyritic andesite (Lambay) in the archaeological record of these respective island societies during the Neolithic, this is an important observation. It suggests that things made from these materials, as well as the processes of object production, use, and deposition, are likely to have played a key role in island social life. In his comment, Hodder also recognizes that jostling with and contained within the notion of this general theoretical agreement are a range of different perspectives, each of which (as their proponents would argue) offers particular insights into the idea that human social life depends on material things. The discussion below applies a number of these perspectives on material culture to the archaeological record of the use 


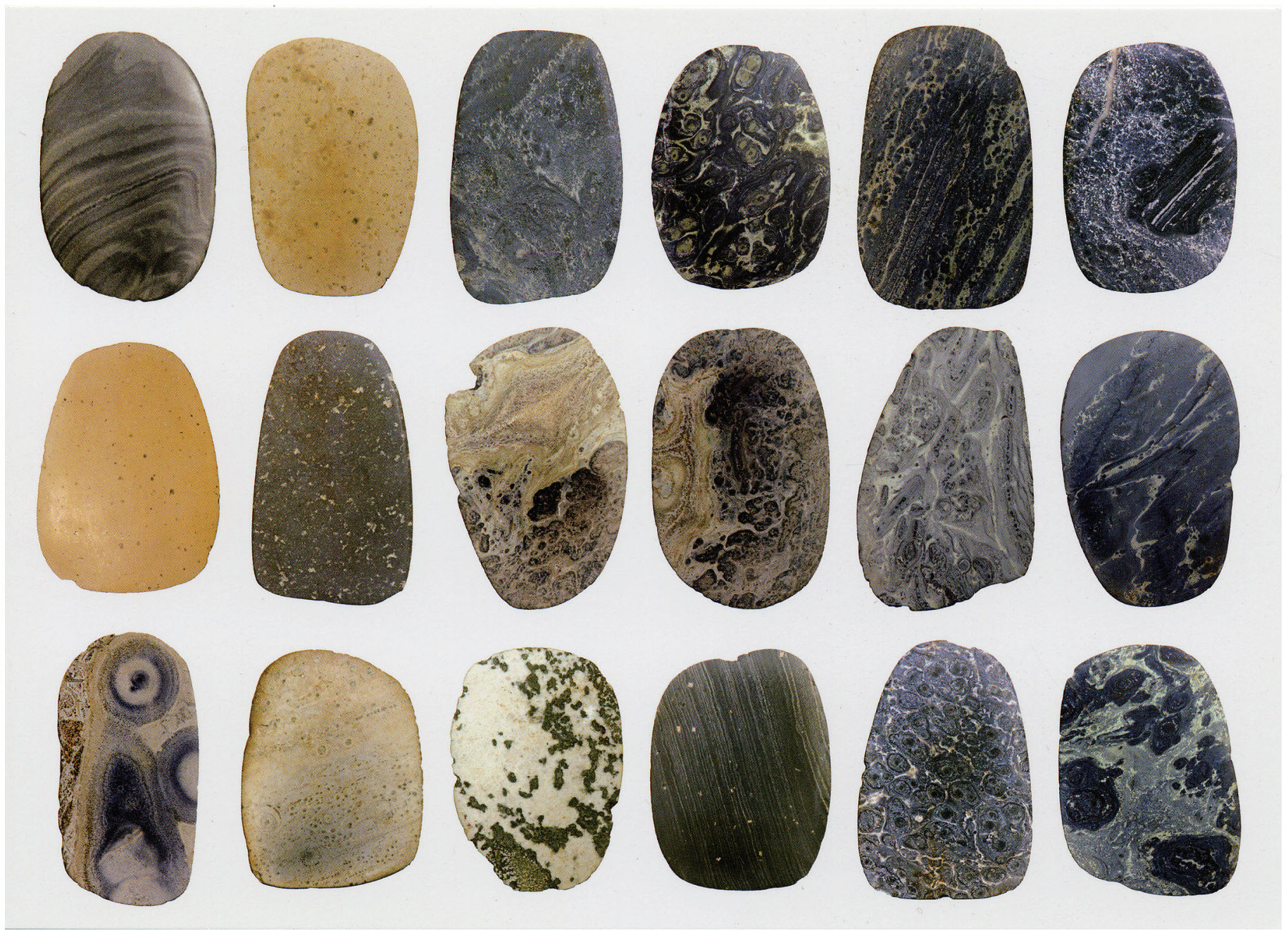

FIG. 3. Felsite knives in the Stourbrough hoard, West Mainland, Shetland. (Photo: Shetland Amenity Trust/D. Piquer)

of these specific island lithic sources on Rathlin, Lambay, and Shetland Islands to examine the extent to which island social life actually depended on them.

\section{STUFF:}

\section{THE STUDY OF MATERIALS AND MATERIALITY}

Within the broader field of the study of material culture, there is a distinctive sub-field known as material culture studies, associated with the work of Miller and colleagues, which focuses particularly on the "stuff" of everyday life in the present (e.g., Miller, 2005, 2008, 2010; Tilley et al., 2006; see Hicks, 2010 for review). Material culture studies were initially focused on what Miller (1987) termed the anthropology of mass consumption. This line of research concentrated on the material world in the present and how consumers transformed items of mass production into objects: things that were used in human social lives. Miller has gone on to develop the argument focusing on what he refers to as the humility of things (Miller, 2010). He argues that the power of things is that they set the scenes we live in and ensure appropriate behaviour, without being open to challenge. Here Miller is explicitly drawing on Bourdieu's (1977) theory of practice, which argues that everyday routines lead to consistent interaction with things, which in turn express underlying cultural patterns. Hence people grow up learning through their material surroundings.

A number of ideas here are useful in looking at the role of the three island lithic sources under discussion. Firstly, looking at the scale and palimpsest of production activities represented at a major stone quarry site such as North Roe, the source of the riebeckite felsite on Shetland (Fig. 5), the idea that organized production of stone axes (and in this particular case also Shetland knives) from specific sources could be represented as mass production is a useful one to think about. After all, stone was extracted and worked into axe and knife roughouts on a large scale, in a repetitive, organized manner over a significant period of time, transforming the quarry landscape, and providing things apparently for the whole of the population of the Shetland archipelago during the Neolithic (Ballin, 2012). The traditional term "axe factory" (e.g., Piggott, 1954) that is still used occasionally in the literature succeeded 


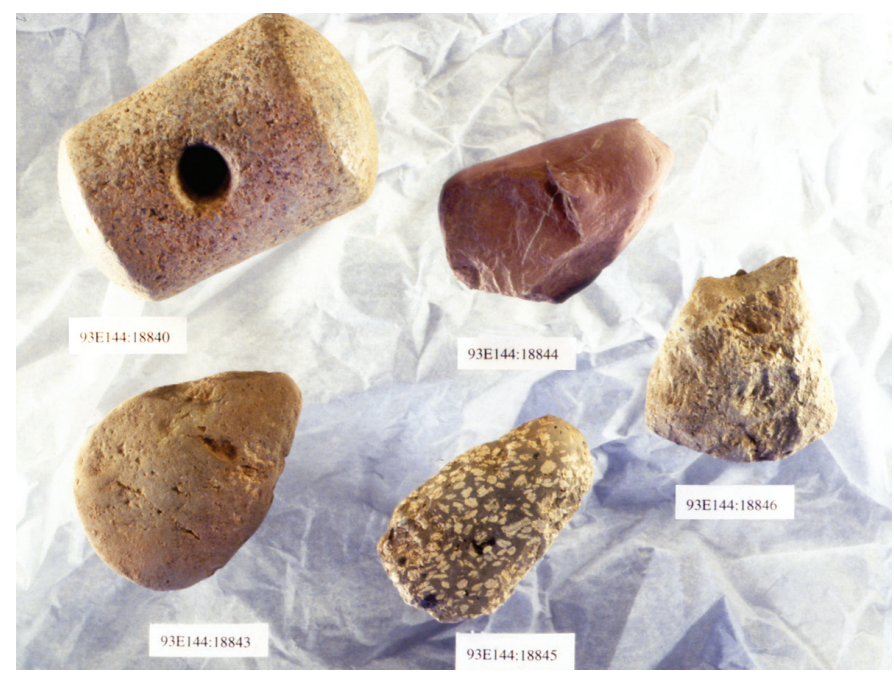

FIG. 4. Hoard of objects from the Eagle's Nest quarry site, Lambay Island, 93E144: 18840 (gabbro), 18843 (sandstone), 18844 (jasper), 18845 and 18846 (porphyry). (Photo: UCD School of Archaeology)

in catching this sense of "industrial" scale. But it is anachronistic, with echoes of regulated, modern work separate from other elements of social life, and for that reason it is inappropriate in the context of small-scale traditional societies.

Miller's approach successfully breaks down the distinction between the use of material culture in traditional and modern societies by blurring the lines between gifts (social) and commodities (economic) (Hicks, 2010). Through material culture studies, we can gain an understanding that it is through quarrying, the processes of transforming stone sources into objects, and handling, using, and disposing of things made from riebeckite felsite, porcellanite, or porphyritic andesite that social relationships were constituted, island lives were lived, and the world understood (Miller, 2008).

The increasing use of the term "materiality" in archaeology (and other disciplines) illustrates this concern with capturing the idea of the social significance of material culture (e.g., Tilley, 2004; Meskell, 2005). The term encapsulates a concern with the study of the physical characteristics of objects, alongside an understanding that humans consciously engage with things and are socially shaped by those engagements (DeMarrais et al., 2004; Knappett, 2012). As Knappett (2012) remarks, there is a tension between emphasis on the physical aspect of materiality and emphasis on its social aspect, as illustrated in the debate sparked by Ingold's (2007) puzzlement that the discussion of materiality and material culture frequently seemed to have little to say about materials. On the other hand, Jones $(2004,2012)$ suggests that materiality provides an approach that actually links materials science and material culture studies: understanding the physical properties of materials and things facilitates an understanding of their social and cultural construction.

When we apply this approach to the island lithic sources under discussion, it is striking that porcellanite, riebeckite

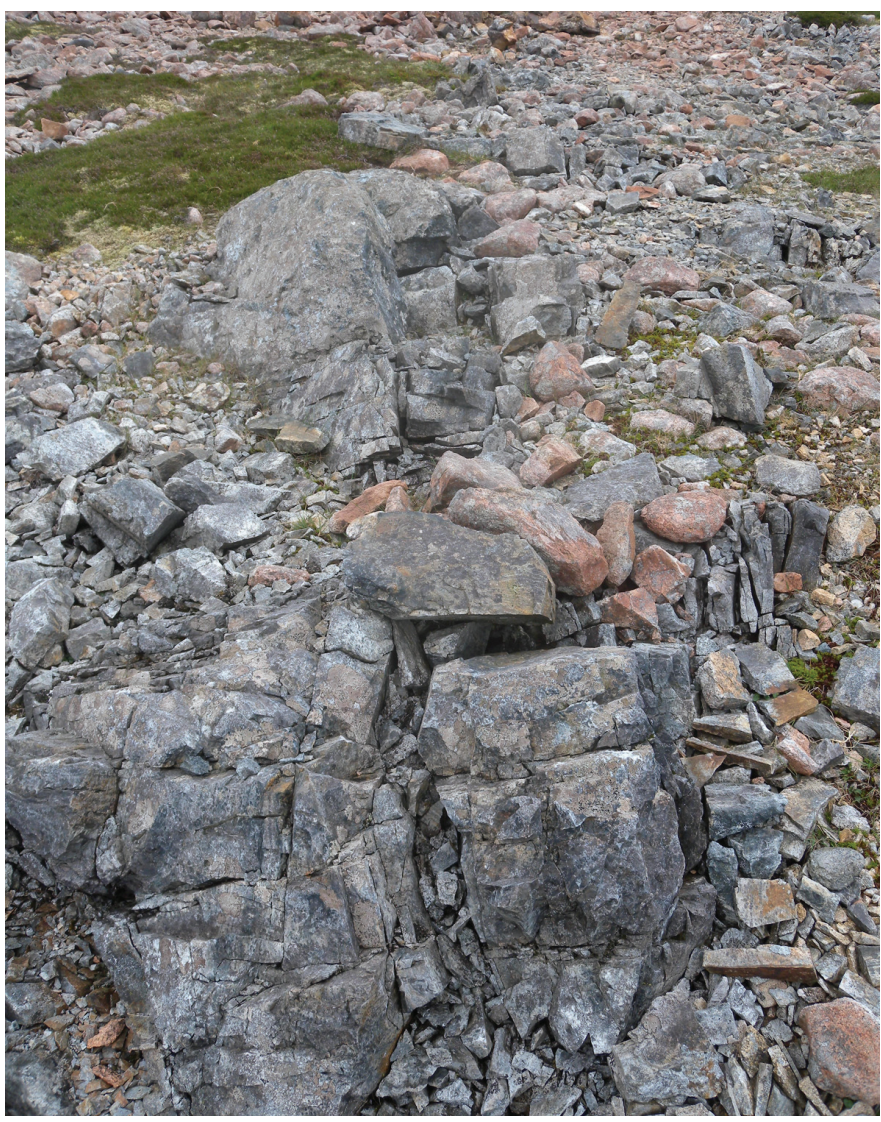

FIG. 5. Quarry area at Beorgs of Uyea within the wider felsite North Roe quarry landscape, Shetland. (Photo: Gabriel Cooney)

felsite, and porphyritic andesite all share the physical property of being visually distinct (see discussion in Cooney, 2002; Cooney and Mandal, 2000; Davis, 2012). The colour variation in their mineralogical and crystalline structure, for example, the phenocrysts in porphyritic andesite or the spherulites in some varieties of felsite, is enhanced through the process of grinding and polishing.

In the case of both riebeckite felsite on Shetland and porphyritic andesite on Lambay, the occurrence of coastal exposures of the rock and polished beach cobbles would have provided tangible evidence of the sensory transformation that the process of grinding and polishing could effect. As both porcellanite and the finer-grained varieties of riebeckite felsite take a conchoidal fracture, grinding and polishing would have followed on and been distinct from the primary process of flaking. This fact would have facilitated the spatial separation of this key stage of the performative relationship between people and the materials from the actual quarry sites. The current lack of evidence for grinding or polishing from the extensive North Roe quarry landscape suggests that riebeckite felsite preforms or roughouts were ground and polished at other locations (Ballin, 2013), while on Rathlin Island there is clear evidence that the working of porcellanite from the quarry at Brockley, including polishing and grinding, was spread across the island and appears to have been part of the activities of daily life (Cooney et al., 2012a). 
Porphyritic andesite, on the other hand, because of its medium to coarse grain, appears to have been worked in a less formally structured sequence of actions; grinding may have begun before the "primary" process of hammering and pecking was completed (Cooney, 2005). The consequence of this informal structure was that all stages of production, including grinding and polishing, took place at the Eagle's Nest quarry site. This fact in turn meant that a wider range of objects had to be brought to the quarry site: not just hammerstones for the initial phases of work, but also grinding stones. As grinding and polishing are known to be the most laborious and time-consuming aspects of the production process, people would have spent more time at the Eagle's Nest quarry site. Perhaps not surprisingly, it became a locus for a range for other activities (see Discussion below). Hence it seems that the materiality of these different lithic sources was created in different ways, which were related very closely to the nature of the materials.

A final relevant point in relation to materiality is the concept of ensemble. The composition of the hoards discussed earlier in the paper, consideration of the places where the stone was worked, and the other objects (e.g., hammerstones and grinding stones) required to produce the items hoarded are reminders that instead of looking at the contents of the hoards as specific, stand-alone materials, it might be useful to engage with the notion of ensemble as another dimension of materiality (Knappett, 2012). This idea is associated particularly with the French tradition of technology studies (e.g., Lemonnier, 2012), in which the social and cultural centrality of things is seen as being located within multiple human-thing relationships in particular contexts (e.g., Coupaye and Douny, 2009).

\section{ENGAGING WITH THE MATERIAL: THINGS ARE US}

A long-standing strand in the study of material culture has been the relationship between cognition and material culture (Renfrew, 2012). In its functional processual phase, cognitive archaeology was defined as the study of past ways of thought inferred from material remains (Renfrew, 1994). Renfrew (2001) redefined the focus of cognitive archaeology, shifting it from the symbolic to materiality and material engagement. There was recognition of the co-dependence of mind and matter through the medium of bodily action and the specific capacities of material and technological environments to have an effect on people (Renfrew, 2007; Boivin, 2008; Malafouris, 2008). From this background there has been the development of material engagement theory, set out initially by Renfrew and Malafouris (e.g., Renfrew, 2004; Malafouris, 2004; Malafouris and Renfrew, 2010) and developed in detail by Malafouris (2013).

The application of material engagement theory is particularly relevant to the case study of Neolithic island lithic sources because of its focus on what Malafouris (2013) refers to as embodied engagement with the world. Instead of a separation of the mind from the realm of materiality and practice (see Knappett, 2005), material engagement theory relates thought, embodied action-taking, and environment, arguing that this relational domain is our way of engaging with the world. Working with stone through the process of extraction, crafting the shape of the object, and creating and changing surroundings by using things made of porcellanite, porphyritic andesite, or riebeckite felsite would all be examples of how mind and things are co-constituted in situated action. Cultural and social meanings emerge from use and performance in this process of embodied engagement (Renfrew, 2012; Malafouris, 2013).

This view is nicely captured by Edmonds and Ferraby $(2013: 35,40)$ in poetically narrating the difference between what might have been an unsuccessful attempt to make a stone axe head...the material in hand remains a stranger. Cold shouldering the hammer's invitation, it refuses to be drawn into the dance... and what happens when the engagement works...The line between hand and material losing its sharpness.
And for all that is inscribed on stone
Much is also written in the body,
Scars of service, build and heft
The body falling into certain shapes,
Like a hammer that drops
Without thinking,
In just the right place.

Hence objects such as stone axes are made by people, but in turn, people are made in the process.

This emphasis on a relational, distributed approach to both people and things is an approach to material culture that material engagement theory shares with symmetrical archaeology. Both perspectives use the concept of humans as a cyborg species (Olsen, 2012; Malafouris, 2013), stressing that the human condition is marked by its complex enmeshment with things (e.g., Webmoor and Witmore, 2008; Olsen, 2010). But while material engagement theory is engaged with the process of making the human mind, symmetrical archaeology focuses on things and on archaeology as the discipline of things (Shanks, 2007). The term derives from Latour's $(1993,2005)$ symmetrical anthropology, the central tenet of which is that the human/ object divide said to have been brought about by modernity is a fallacy. The argument is that in the present, as in the past, the human condition is a meshwork of relations between people and non-humans. Inspired by this idea, advocates of symmetrical archaeology argue that what sets this approach apart is its explicit focus on things, in contrast to other perspectives on material culture that use things to reach their real objective, the study of people (Olsen et al., 2012).

Conscious of the ongoing debate about this focus on things rather than people (e.g., Barrett, 2014; Olsen and 
Witmore, 2015; Thomas, 2015), here I take symmetrical archaeology as providing us with two important insights when we come to look at island lithic sources. The first is the need to focus more on materials and things in their own right, and the second is the recognition that as archaeologists, we approach the material record of the past through a set of standardized technologies, creating a distinct ecology of practices (Olsen et al., 2012).

Hence it is useful to look at the things or objects from the three island sources themselves in more detail. For example, while the term "axe" is used as a general label, in fact this term covers a number of object types (axes, adzes, chisels, and wedges) that encompass a wide range of functions and roles. Those functions appear to have been more utilitarian in some cases, but more ceremonial in others. This distinction can be appreciated in terms of the size of axe heads (e.g., Cooney, 2000). For example, it would appear that one strand in the working of porcellanite was channeled toward the production of large axes with oblique butts (Cooney and Mandal, 1998). In his analysis of riebeckite felsite axes and knives from the North Roe quarry on Shetland, Ballin $(2013,2015)$ concludes that we can identify both functional and ceremonial channels in both types of object from the preform or roughout stage, through to the degree and care of polish and finish, to the function and context, and finally, in the patterns of deposition. In the case of porphyritic andesite at the Eagle's Nest quarry (Fig. 6), one striking aspect was the variety of ways in which this material was used. First, it was a raw material for axes. Second, suitably shaped blocks were set up as anvil stones in areas of debitage build-up. Third, other blocks became the focus for structured deposition around them when they were deposited in pits or on the surface. And of course, there is the accumulation of debitage itself. Coming to this rich and varied material record, it is worth remembering that as archaeologists we impose our ecology of practices in trying to understand the meaningful engagement of people and things in the past. Hence our understanding of the role of porcellanite, riebeckite felsite, and porphyritic andesite is based on earlier research on museum collections and in the field that demonstrated there were significant numbers of objects that could literally be seen to be made of the same materials (e.g., for riebeckite felsite; Phemister et al., 1952; Ritchie, 1968; Ritchie and Scott, 1988). Fieldwork and petrological analysis established the links between the objects and the sources they came from. Mapping of the contexts of location and circumstances of discovery provided information on the movement and use of the objects. Finally, and perhaps most poignantly, excavation at quarry sites unpicks and tries to establish the organizational web behind the palimpsestic archaeological record of quarry faces, extraction pits, workshops and episodes of working stone (Fig. 7). We work in reverse order to untangle the beginnings of the lives of axes and related objects.

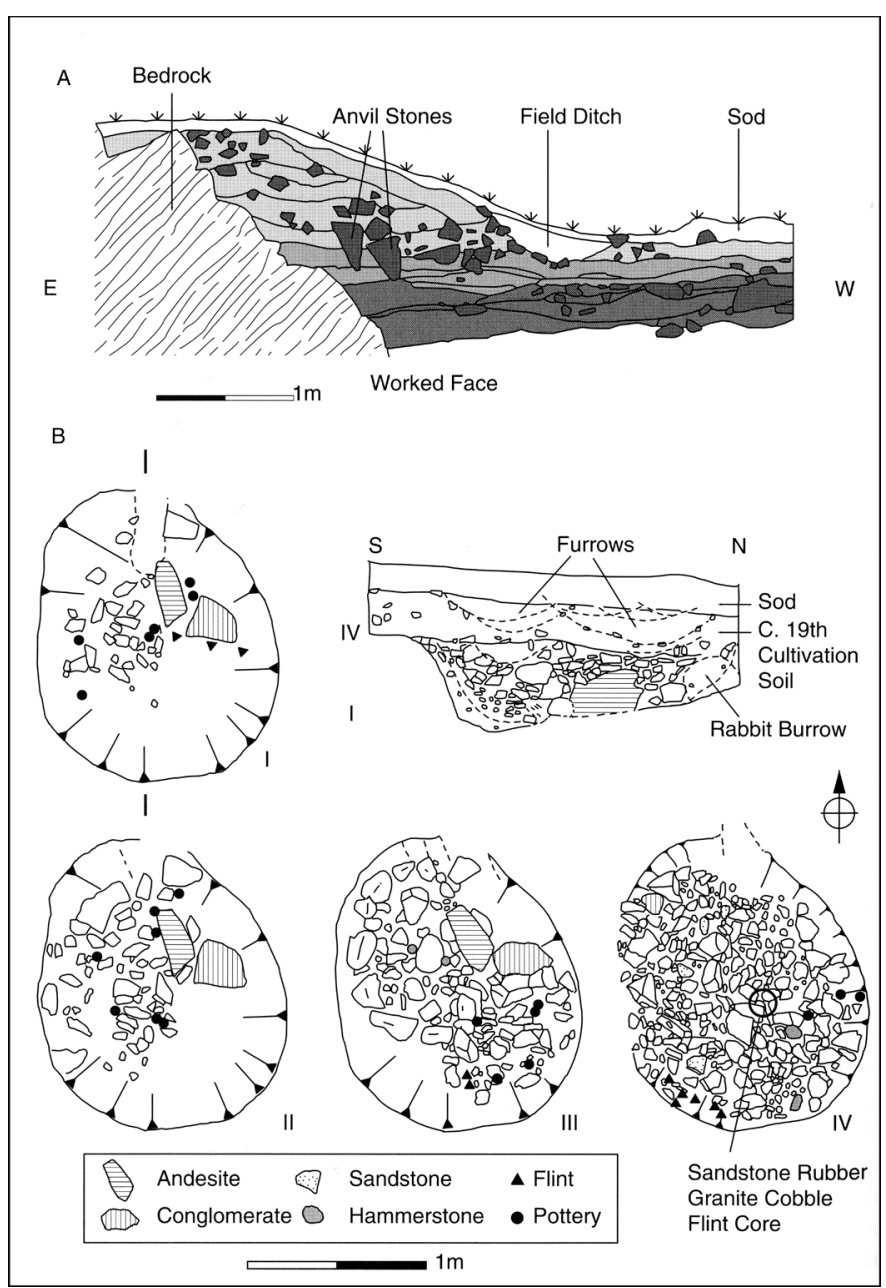

FIG. 6. Eagle's Nest, Lambay Island: A) Quarried rock face and debitage buildup, B) Structured deposition in a pit focused on andesite slabs.

\section{THE ENTANGLED LIVES OF ISLAND THINGS}

This reference to entanglement is in recognition of the approach championed by Hodder (2011a, 2012a). The central strength of entanglement, according to Hodder (2012a), is the recognition that humans depend on things, things depend on other things, things depend on humans, and humans depend on humans. Hodder argues that the processes of transformation and constraint in society are not in the material facts of existence but in these dependences between humans and things, and the contingent ways in which multiple strands of entanglement are tied together.

Perhaps not surprisingly, Hodder's most detailed and convincing examples of the ongoing, locally, and practically worked-out character of entanglement come from his own long-term engagement with the Neolithic site of Çatalhöyük in Turkey and the origins of agriculture in the Middle East (e.g., Hodder, 2011b, 2012a). He argues that amongst a range of resources at Çatalhöyük, clay (as in houses and pots) was a critical one (e.g., Hodder, 2012a). It is useful to think of stone as filling the same critical role, alongside the use of a variety of materials, on islands like 


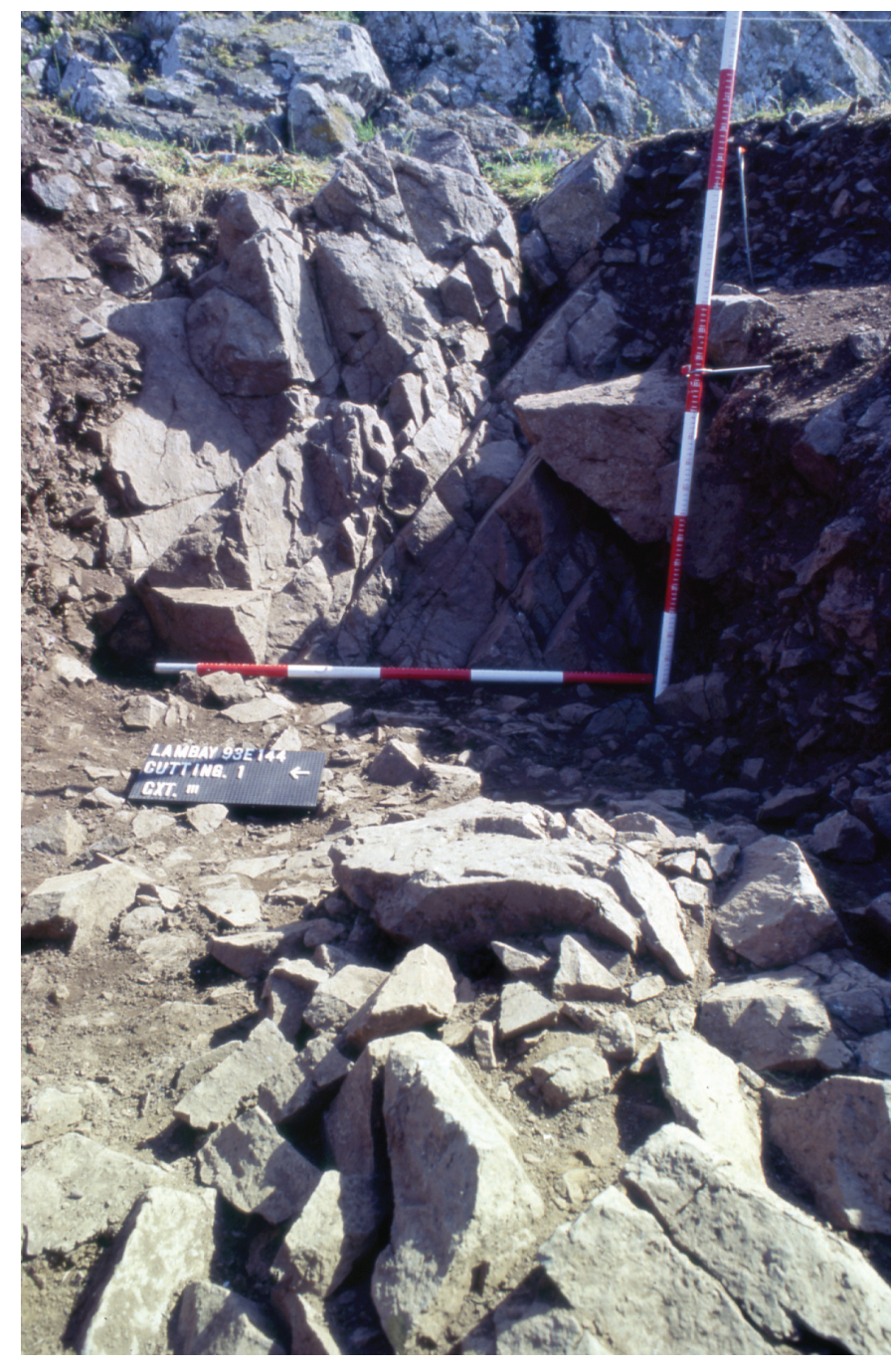

FIG. 7. Excavated quarry face and surface of working floor with debitage, Eagle's Nest site, Lambay Island. (Photo: Gabriel Cooney)

Shetland, Rathlin, and Lambay in northwestern Europe during the Neolithic (see Boivin, 2004; Cooney, 2008). The impetus to begin organized production of axes and other objects from specific sources appears to be tied in with the shift to agriculture and its implied transformation of landscape, in which the axe became an important functional and symbolic asset (e.g., Whittle, 2003; Whittle et al., 2011). Even though in island environments forest clearance may have been a relatively rapid process (see Sheridan, 2012) and island life is likely to have focused on foraging as well as farming (e.g., Montgomery et al., 2013), the entanglement of axes as an aspect of what being Neolithic meant may have been what brought about the initial quest to exploit particular resources.

Once quarries were operational and objects from them were circulating and in use-as tools, as weapons, materializing the bonds between people, being broken and re-used, disposed of casually or deposited carefullythis use may have created the need for continuation of production and complicated notions of the temporalities associated with axe production (e.g., Bailey, 2007). The material engagement with an axe ranged from the relative rapidity of time in which a preform or roughout could be produced, the different pace (and patience) that was required to grind and polish it, and the circulation and use of the axe, which may have extended beyond individual human lives and become caught up in ideas of history and place. The quarries themselves were places transformed by the processes involved in making preforms or roughouts (e.g., Nyland, 2015; Topping, 2017). When people went back to quarries, there was evidence of previous activity. At the Eagle's Nest, the glacially polished outcrop faces that may have brought people to the site initially were removed and the faces marked by scarring. In the case of Brockley on Rathlin Island, galleries were created in the porcellanite outcrop. At North Roe, alongside felsite dykes that were lightly exploited, other dykes, particularly at the Beorgs of Uyea, were heavily worked (Fig. 5); large areas of them were removed and extraction pits were created as people sought greater access to the outer areas of the dykes, the chilled margin with the granite country rock that seems to have been particularly favoured as a raw material (Cooney et al, 2017).

In understanding the processes of production and transformation at such quarry sites, the chaîne opératoire provides a widely used methodological framework for reconstructing processes by which materials are chosen, shaped, and transformed into things (e.g., Pelegrin, 1993). As Schlanger (2005) points out, this framework also aims to understand the nature and role of technical activities in past human societies, hence taking us beyond production processes. The notion of using shifting and interlocking scales of analysis when looking at the relationships between tasks, people, and the wider landscape, as suggested for example by Lemonnier (1993) and Conneller (2008), is reminiscent of Hodder's entanglement approach. Lemonnier's (2012) idea of ensemble mentioned above expresses the mesh of social meanings built around the physical characteristics of things and the material ways people interact with them.

It is useful to think about these ideas of entanglement and ensemble in relation to the chaine opératoire involved in the production and use of the island sources discussed here. The chaine opératoire approach tends to focus on success, but of course part of what we see in the build-up of material at quarry sites like North Roe on Shetland (Fig. 5) or the Eagle's Nest on Lambay (Figs. 6 and 7)-including the broken preforms and roughouts, the debitage at sites like Craigmacagan on Rathlin (Logue et al., 2012), or the sites identified by Ballin (2103) on Shetland, such as Firths Voe, where felsite objects were reworked - is the need to cope with failure as well as success (Cooney, 1998). Even in societies enmeshed with the working of stone, there were risks involved: things did not always work out.

Against this background, it is useful to return to the idea that things have lives. The "object biography" approach was first put forward by Kopytoff (1986), who suggested that just as we write human biographies, we could think of 
objects in the same way. Objects are produced (born), are used (have an active life), and are discarded or deposited (die). Given the emphasis in this approach on examining the relationship between people and objects (Gosden and Marshall, 1999), it is not surprising that many such studies focus on exchange and circulation. However, as Joy (2009) points out, the difficulty that archaeologists have in reconstructing object biographies is that they most often deal with objects whose social life was ended through discard or deposition (see LaMotta, 2012). Joy (2009) suggests that in dealing with this problem, archaeologists should draw on the biographical information in the artifact itself and recognize the non-linear biographies of objects. This approach facilitates setting objects in the contexts of the social relationships that constitute and activate them.

Returning to the example of the three hoards with which we started, in each case we are dealing with an ensemble of objects deliberately brought together. The focus is on one of the three lithic sources discussed, but in each hoard other objects are drawn in that are linked to the lives of the axes (or in the case of the Stourbrough hoard, the Shetland knives). Linking the references to production and the early lives of objects in the hoards (the preforms or roughouts and the sandstone blocks) to the placement of material in the ground, it is tempting to see a link being made to a circular (rather than linear) concept of the biographies of objects, in which the beginnings and ends of the biographical cycle are cross-referenced. This link is particularly striking in the case of the hoard at the Eagle's Nest on Lambay, where the hoard is deposited at a quarry site.

\section{DISCUSSION: MAKING ISLAND WORLDS}

If there is an overarching theme that has emerged from looking at Neolithic life on these three islands in the context of different approaches to understanding things, it is the prominence of the three lithic sources, indicating that they were central to how people engaged with and created their island places and landscapes. Robb and Miracle (2007) suggest that prehistoric people actively and continuously evaluated and reinvented traditions from a repertoire of available possibilities. As a focal material resource in Neolithic northwestern Europe on islands like the three under scrutiny here, stone was central to those processes of engagement, evaluation, and reinvention. Through people's daily engagement with different stone sources (including the ones focused on here) and at different scales (from object to monument), social relationships and conventions were created and sustained.

Of course, this engagement is heightened by the physical reality that the sea lays down clear boundaries around an island. As the novelist Andrew Greig (2004) put it, within islands everything is intensified. This idea feeds into the view of islands as valuable small-scale laboratories of social change because they are places that can be explored and comprehensively understood. On the other hand, the reality is that islands and mainlands are linked by the movement of people and things across the sea (e.g., Broodbank, 2000; Van de Noort, 2011) and that landscapes are complemented by seascapes (Renouf, 2011a, b). The importance of stone from island sources is that they allow us to explore the complementary relationship between the notion of islands as fixed, bounded places and the fluidity and inter-connectivity of islands and mainlands created by the movement of people (see Cooney et al., 2013). In the case of the porphyritic andesite from Lambay, while small numbers of axes from this island source are found on the Irish mainland, the majority that we know of were actually deposited at the quarry itself. By contrast, it is clear that the majority of porcellanite axes from Brockley were brought off the island and contributed to the widespread distribution of porcellanite axes in Ireland and Britain, as far north as Shetland (Sheridan, 2012). Felsite axes from the North Roe quarry appear to have been used predominantly in the Shetland archipelago, but their widespread distribution suggests that they played an important role as a material manifestation of a sense of cultural identity across the island group. As mentioned above, there is a wider trend of using island sources to produce axes in the Neolithic (Cooney, 2015). What the detailed discussion of the three sources here indicates is that within that broad trend, we should recognize that the material engagement with island sources during the Neolithic must be seen as specific to particular island circumstances and resources. As Robb (2001) put it in relation to Neolithic Malta, regional symbolic heritage would have been reworked in the context of locally (island-) grounded identity.

In attempting to draw out the importance of these island lithic sources, I have discussed a number of approaches. Clearly there are others, such as the life history approach (e.g., LaMotta, 2012) or fragmentation (Chapman, 2000), that would have been useful, but the perspective I have adopted could be seen as combining different theoretical insights into the study of things while recognizing the differences and tensions between them (see Olsen, 2010). This approach also illustrates Hodder's (2011a, 2012b) conclusion that we have a reached a stage where there is broad agreement that humans and social life depend on things and that there is value to be gained by comparing different approaches and points of agreement between them, rather than the differences that (perhaps inevitably) tend to be emphasized in the literature (e.g., Tilley, 2007; Renfrew, 2012).

The focus of this paper has been the role of lithic sources in the Neolithic cultural landscapes of three islands. As Priscilla Renouf (2011b) recognized, landscapes become enculturated as people experience them. People turn them into places permeated with knowledge, memory, history, identity, and emotion. In the case of Lambay, Rathlin, and Shetland Islands, things made from key stone sources played a central role in those human processes during the Neolithic. 


\section{ACKNOWLEDGEMENTS}

It is a pleasure to have the opportunity to contribute to this special issue of Arctic in honour of Priscilla Renouf, a friend and colleague who enriched my understanding of all aspects of Newfoundland archaeology and culture and how life should be lived. I would like to thank the editor and anonymous referees for their comments, which improved the quality of the paper. For their assistance in its preparation, I am very grateful to Conor McDermott, Joanne Gaffrey, and Conor McHale.

\section{REFERENCES}

Appadurai, A., ed. 1986. The social life of things: Commodities in cultural perspective. Cambridge: Cambridge University Press.

Bailey, G. 2007. Time perspectives, palimpsests and the archaeology of time. Journal of Anthropological Archaeology 26(2):198-223. https://doi.org/10.1016/j.jaa.2006.08.002

Ballin, T.B. 2011a. The felsite quarries of North Roe, Shetland An overview. In: Davis, V., and Edmonds, M., eds. Stone axe studies III. Oxford: Oxbow. 121-130.

- 2011b. The felsite quarry complex of Northmaven: Observations from a fact-finding mission to Shetland. In: Saville, A., ed. Flint and stone in the Neolithic period. Oxford: Oxbow. 62-81.

2012. The distribution of worked felsites - within and outwith Neolithic Shetland. In: Mahler, D.L., ed. The border of farming and the cultural markers. Copenhagen: National Museum of Denmark. 62-78.

- 2013. Felsite axehead reduction - the flow from quarry pit to discard/deposition. In: Mahler, D.L., ed. The border of farming - Shetland and Scandinavia: Neolithic and Bronze Age farming. Copenhagen: National Museum of Denmark. $73-91$.

- 2015. Felsite polished stone axehead/adzes and Shetland knives in Shetland Museum - recording, characterization, and interpretation of the collection. North Roe Felsite Project Report 2. Dublin: University College Dublin, School of Archaeology.

Barrett, J.C. 2014. The material constitution of humanness. Archaeological Dialogues 21(1):65-74.

https://doi.org/10.1017/S1380203814000105

Boivin, N. 2004. From veneration to exploitation: Human engagement with the mineral world. In: Boivin, N., and Owoc, M.A., eds. Soils, stones and symbols: Cultural perceptions of the mineral world. London: UCL Press. 1-29.

- 2008. Material cultures, material minds: The impact of things on human thought, society, and evolution. Cambridge: Cambridge University Press.

Bourdieu, P. 1977. Outline of a theory of practice, trans. by R. Nice. Cambridge: Cambridge University Press.

Broodbank, C. 2000. An island archaeology of the Early Cyclades. Cambridge: Cambridge University Press.
Chapman, J. 2000. Fragmentation in archaeology: People, places and broken objects in the prehistory of south-eastern Europe. London: Routledge.

Conneller, C. 2008. Lithic technology and the chaîne opératoire. In: Pollard, J., ed. Prehistoric Britain. Oxford: Blackwell. $160-176$.

Cooney, G. 1998. Breaking stones, making places: The social landscape of axe production sites. In: Gibson, A.M., and Simpson, D.D.A., eds. Prehistoric ritual and religion: Essays in honour of Aubrey Burl. Stroud: Sutton. 108-118.

- 2000. Landscapes of Neolithic Ireland. London: Routledge.

2002. So many shades of rock: Colour symbolism in Irish stone axeheads. In: Jones, A., and MacGregor, G., eds. Colouring the past: The significance of colour in archaeological research. Oxford: Berg. 93-107.

— 2005. Stereo porphyry: Quarrying and deposition on Lambay Island, Ireland. In: Topping, P., and Lynott, M., eds. The cultural landscape of prehistoric mines. Oxford: Oxbow. $14-29$.

- 2008. Engaging with stone: Making the Neolithic in Ireland and western Britain. In: Fokkens, H., Coles, B.J., Van Gijn, A.L., Kleijne, J.P., Ponjee, H.H., and Slappendel, C.G., eds. Between foraging and farming: An extended broad spectrum of papers presented to Leendert Louwe Kooijmans. Analecta Praehistorica Leidensia 40. 203-214.

2009. The prehistory of Lambay, a long view. In: Baker, C., ed. Axes, warriors and windmills: Recent archaeological discoveries in North Fingal. Swords: Fingal County Council. $8-22$.

_., ed. 2011. New approaches to stone mines and quarries: Materials and materiality. World Archaeology 43(2):145-341.

- 2015. Stone and flint axes in Neolithic Europe. In: Fowler, C., Harding, J., and Hofmann, D., eds. The Oxford handbook of Neolithic Europe. Oxford: Oxford University Press. 515-534.

- 2016. Material culture. In: Gardner, A., Lake, M., and Sommer, U., eds. The Oxford handbook of archaeological theory. Oxford: Oxford University Press.

https://doi.org/10.1093/oxfordhb/9780199567942.013.019

Cooney, G., and Mandal, S. 1998. Irish stone axe project. Monograph I. Dublin: Worldwell.

. 2000. The Irish stone axe project: Sources for stone axes in Ireland. Krystalinikum 26:45-55.

Cooney, G., Mandal, S., O’Keeffe, E., and Warren, G. 2012a. Rathlin in early prehistory. In: Forysthe, W., and McConkey, R., eds. Rathlin Island: An archaeological survey of a maritime landscape. Belfast: The Stationery Office/Northern Ireland Environment Agency. 46-55, 62-74, 82-85.

Cooney, G., Mandal, S., O'Keeffe, E., Warren, G., Ballin, T., and Megarry, W. 2012b. Axes from islands: The role of stone axeheads from insular sources in the Neolithic of Britain and Ireland. In: Mahler, D.L., ed. The border of farming and the cultural markers. Copenhagen: National Museum of Denmark. 79-99.

Cooney, G., Ballin, T., and Warren, G. 2013. Island quarries, island axeheads, and the Neolithic of Britain and Ireland. North American Archaeologist 34(4):409-431. 
Cooney, G., Gaffrey, J., Gilhooly, B., Megarry, W., O’Neill, B., and Sands, R. 2017. NRFP 2014 and 2016 Seasons. North Roe Felsite Project Report 4. Dublin: University College Dublin, School of Archaeology.

Cordier, G., and Bocquet, A. 1998. Le dépôt de le Bégude-de Mazenc (Drôme) et les dépots de haches néolithiques en France. Note complémentaire. Bulletin de la Société préhistorique française 95(2):221 - 238.

Coupaye, L., and Douny, L. 2009. Dans la trajectoire des choses: Comparaison des approches francophones at anglophones contemporaines en anthropologie des techniques. Techniques et Culture 52(3):12-39.

Davis, R.V. 2012. A preliminary report on the petrographic survey of the Neolithic stone quarries and stone tool manufacturing sites at North Roe, Shetland, May 2012. Unpubl. report available at UCD School of Archaeology, University College Dublin, Dublin 4, Ireland.

DeMarrais, E., Gosden, C., and Renfrew, C. 2004. Introduction. In: DeMarrais, E., Gosden, C., and Renfrew, C., eds. Rethinking materiality: The engagement of mind with the material world. Cambridge: McDonald Institute for Archaeological Research. $1-7$.

Edmonds, M., and Ferraby, R. 2013. Stonework. Orkney: Group 6 Press.

Fojut, N. 2006. Prehistoric and Viking Shetland. Lerwick: Shetland Times.

Gosden, C., and Marshall, Y. 1999. The cultural biography of objects. World Archaeology 31(2):169-178.

Greig, A. 2004. In another light. London: Weidenfield and Nicholson.

Hicks, D. 2010. The material-culture turn: Event and effect. In: Hicks, D., and Beaudry, M.C., eds. The Oxford handbook of material culture studies. Oxford: Oxford University Press. $25-98$.

Hodder, I. 2011a. Human-thing entanglement: Towards an integrated archaeological perspective. Journal of the Royal Anthropological Institute 17(1):154-177.

- 2011b. The leopard's tale: Revealing the mysteries of Çatalhöyük. London: Thames and Hudson.

- 2012a. Entangled: An archaeology of the relationships between humans and things. Oxford: Wiley-Blackwell.

- 2012b. Introduction: Contemporary theoretical debate in archaeology. In: Hodder, I., ed. Archaeological theory today, $2^{\text {nd }}$ ed. Cambridge: Polity Press. 1-14.

Hoskins, J. 1998. Biographical objects: How things tell the stories of people's lives. London: Routledge.

Ingold, T. 2007. Materials against materiality. Archaeological Dialogues 14(1):1-16.

https://oi.org/10.1017/S1380203807002127

Jones, A.M. 2004. Archaeometry and materiality: Materials-based analysis in theory and practice. Archaeometry 46(3):327-338. https://doi.org/10.1111/j.1475-4754.2004.00161.x

_ 2012. Prehistoric materialities: Becoming material in prehistoric Britain and Ireland. Oxford: Oxford University Press.

Joy, J. 2009. Reinvigorating object biography: Reproducing the drama of object lives. World Archaeology 41(4):540 - 556. https://doi.org/10.1080/00438240903345530
Knappett, C. 2005. Thinking through material culture: An interdisciplinary perspective. Philadelphia: University of Pennsylvania Press.

- 2012. Materiality. In: Hodder, I., ed. Archaeological theory today, $2^{\text {nd }}$ ed. Cambridge: Polity Press. 188-207.

Kopytoff, I. 1986. The cultural biography of things: Commoditization as a process. In Appadurai, A., ed. The social life of things: Commodities in cultural perspective. Cambridge: Cambridge University Press. 64-91.

LaMotta, V.M. 2012. Behavioral archaeology. In: Hodder, I., ed. Archaeological theory today, $2^{\text {nd }}$ ed. Cambridge: Polity Press. 62-92.

Latour, B. 1993. We have never been modern, trans. by C. Porter. London: Harvard University Press.

- 2005. Reassembling the social: An introduction to actor network-theory. Oxford: Oxford University Press.

Lemonnier, P., ed. 1993. Introduction. In: Lemonnier, P., ed. Technological choices: Transformation in material cultures since the Neolithic. London: Routledge. 1-35.

- 2012. Mundane objects: Materiality and non-verbal communication. Walnut Creek, California: Left Coast Press.

Logue, R., Roche, H., and Mandal, S. 2012. Excavations at Craigmacagan. In: Forsythe, W., and McConkey, R., eds. Rathlin Island: An archaeological survey of a maritime landscape. Belfast: The Stationery Office/Northern Ireland Environment Agency. 74-81.

Malafouris, L. 2004. The cognitive basis of material engagement: Where brain, body and culture conflate. In: DeMarrais, E., Gosden, C., and Renfrew, C., eds. Rethinking materiality: The engagement of mind with the material world. Cambridge: McDonald Institute for Archaeological Research. 53-62.

- 2008. Between brains, bodies and things: Tectonoetic awareness and the extended self. Philosophical Transactions of the Royal Society of London Series B 363(1499):1993-2002. https://doi.org/10.1098/rstb.2008.0014

- 2013. How things shape the mind: A theory of material engagement. Cambridge, Massachusetts: The MIT Press.

Malafouris, L., and Renfrew, C. 2010. Introduction: Cognitive life of things: Archaeology, material engagement and the extended mind. In: Malafouris, L., and Renfrew, C., eds. The cognitive life of things: Recasting the boundaries of the mind. Cambridge: McDonald Institute for Archaeological Research. $1-12$.

Meskell, L., ed. 2005. Archaeologies of materiality. Oxford: Wiley Blackwell.

Miller, D. 1987. Material culture and mass consumption. Oxford: Basil Blackwell.

—., ed. 2005. Materiality. Durham, North Carolina: Duke University Press.

- 2008. The comfort of things. Cambridge: Polity Press. - 2010. Stuff. Cambridge: Polity Press.

Montgomery, J., Beaumont, J., Jay, M., Keefe, K., Gledhill, A.R., Cook, G.T., Dockrill, S.J., and Melton, N.D. 2013. Strategic and sporadic marine consumption at the start of the Neolithic: Increasing temporal resolution in the isotope data. Antiquity 87(338):1060-1072.

https://doi.org/10.1017/S0003598X00049863 
Nyland, A.J. 2015. Humans in motion and places of essence: Variations in rock procurement practices in the Stone, Bronze and Early Iron Ages, in southern Norway. PhD thesis, Department of Archaeology, Conservation and History, University of Oslo.

Olsen, B. 2010. In defense of things: Archaeology and the ontology of objects. Lanham, Maryland: AltaMira Press.

—. 2012. Symmetrical archaeology. In: Hodder, I., ed. Archaeological theory today, $2^{\text {nd }}$ ed. Cambridge: Polity Press. 208-228.

Olsen, B., and Witmore, C. 2015. Archaeology, symmetry and the ontology of things: A response to critics. Archaeological Dialogues 22(2):187-197.

https://doi.org/10.1017/S1380203815000240

Olsen, B., Shanks, M., Webmoor, T., and Witmore, C. 2012. Archaeology: The discipline of things. Berkeley: University of California Press.

Pelegrin, J. 1993. A framework for analysing prehistoric stone tool manufacture and a tentative application to some early lithic industries. In: Berthelet, A., and Chavaillon, J., eds. The use of tools by human and non-human primates. Oxford: Clarendon Press. 302-314.

Pétrequin, P., Milleville, A., and Pétrequin, A.-M. 2012. Planches dessin des grandes haches trouvées en dépot. In: Pétrequin, P., Cassen, S., Errera, M., Klassen, L., Sheridan, A., and Pétrequin, A.-M., eds. JADE: Grandes haches alpines du Néolithique européen. $\mathrm{V}^{\mathrm{e}}$ et $\mathrm{IV}^{\mathrm{e}}$ millénaires av. J.-C. Besançon: Presses universitaires de Franche-Comté. 1462-1502.

Phemister, J., Harvey, C.O., and Sabine, P.A. 1952. The riebeckitebearing dykes of Shetland. Mineral Magazine 29:359-373.

Piggott, S. 1954. The Neolithic cultures of the British Isles. Cambridge: Cambridge University Press.

Renfrew, C. 1994. Towards a cognitive archaeology. In: Renfrew, C., and Zubrow, E.B.W., eds. The ancient mind: Elements of cognitive archaeology. Cambridge: Cambridge University Press. 3-12.

- 2001. Symbol before concept: Material engagement and the early development of society. In: Hodder, I., ed. Archaeological theory today, $1^{\text {st }}$ ed. Cambridge: Polity Press. $122-140$.

- 2004. Towards a theory of material engagement. In: DeMarrais, E., Gosden, C., and Renfrew, C., eds. Rethinking materiality: The engagement of mind with the material world. Cambridge: McDonald Institute for Archaeological Research. 23-32.

- 2007. Prehistory: The making of the human mind. London: Weidenfeld and Nicolson.

—. 2012. Towards a cognitive archaeology: Material engagement and the early development of society. In: Hodder, I., ed. Archaeological theory today, $2^{\text {nd }}$ ed. Cambridge: Polity Press. 124-145.

Renouf, M.A.P. 2011a. Introduction: Archaeology at Port au Choix. In: Renouf, M.A.P., ed. The cultural landscapes of Port Au Choix: Precontact hunter-gatherers of northwestern Newfoundland. New York: Springer. 1-20. 2011b. The life history of Port au Choix landscapes. In: Renouf, M.A.P., ed. The cultural landscapes of Port Au Choix: Precontact hunter-gatherers of northwestern Newfoundland. New York: Springer. 271-300.

Ritchie, P.R. 1968. The stone implement trade in third millennium Scotland. In: Coles, J.M., and Simpson, D.D.A., eds. Studies in ancient Europe: Essays presented to Stuart Piggott. Leicester: Leicester University Press. 117-136.

Ritchie, P.R., and Scott, J.G. 1988. The petrological identification of stone axes from Scotland. In: Clough, T.H.McK., and Cummins, W.A., eds. Stone axe studies, Vol. 2: The petrology of prehistoric stone implements from the British Isles. London: CBA Research Report 67:85-91.

Robb, J. 2001. Island identities: Ritual, travel and the creation of difference in Neolithic Malta. European Journal of Archaeology 4(2):175-202.

https://doi.org/10.1179/eja.2001.4.2.175

Robb, J., and Miracle, P. 2007. Beyond 'migration' versus 'acculturation': New models for the spread of agriculture. Proceedings of the British Academy 144:99-115.

Schlanger, N. 2005. The chaîne opératoire. In: Renfrew, C., and Bahn, P., eds. Archaeology: The key concepts. London: Routledge. 25-31.

Shanks, M. 2007. Symmetrical archaeology. World Archaeology 39(4):589-596. https://doi.org/10.1080/00438240701679676

Sheridan, A. 2012. Neolithic Shetland: A view from the "mainland." In: Mahler, D.L., ed. The border of farming and the cultural markers. Copenhagen: National Museum of Denmark. 6-36.

Thomas, J. 2015. Why 'the death of archaeological theory'? In: Hillerdal, C., and Siapkas, J., eds. Debating archaeological empiricism: The ambiguity of material evidence. London: Routledge. $11-31$.

Tilley, C. 2004. The materiality of stone: Explorations in landscape phenomenology. Oxford: Berg.

- 2007. Materiality in materials. Archaeological Dialogues 14(1):16-20.

Tilley, C., Keane, W., Küchler, S., Rowlands, M., and Spyer, P., eds. 2006. Handbook of material culture. London: Sage.

Topping, P. 2017. The social context of prehistoric extraction sites in the U.K. PhD thesis, Newcastle University.

Van de Noort, R. 2011. North Sea archaeologies: A maritime biography 10,000 BC - AD 1500. Oxford: Oxford University Press.

Webmoor, T., and Witmore, C.L. 2008. Things are us! A commentary on human/things relations under the banner of a 'social' archaeology. Norwegian Archaeological Review 41(1):53-70.

Whittle, A. 2003. The archaeology of people: Dimensions of Neolithic life. London: Routledge.

Whittle, A., Healy, F., and Bayliss, A. 2011. Gathering time: Dating the Early Neolithic enclosures of southern Britain and Ireland. Oxford: Oxbow. 